Pak. j. sci. ind. res. Ser. B: biol. sci. 2018 61B(1) 56-58

\title{
Short Communication \\ Role of Potassium in Reducing Oxidative Damage in Maize under Salt Stress
}

\author{
Muhammad Suhaib**, Asma Mujtaba ${ }^{\mathrm{b}}$, Muhammad Arshad Ullah ${ }^{\mathrm{a}}$, Badar-uz-Zamana \\ Imdad Ali Mahmood ${ }^{a}$, Hafiz Muhammad Asadullah' ${ }^{\mathrm{c}}$ and Muhammad Jahanzaib ${ }^{\mathrm{c}}$ \\ ${ }^{a}$ Land Resources Research Institute, NARC, Islamabad, Pakistan \\ ${ }^{b}$ Institute of Soil and Environmental Sciences, University of Agriculture Faisalabad, Pakistan \\ ${ }^{\mathrm{c}}$ Crop Sciences Institute, NARC, Islamabad, Pakistan
}

(received August 24, 2016; revised February 6, 2017; accepted May 10, 2017)

\begin{abstract}
Hydroponic experiment was carried out to assess the effect of $\mathrm{K}$ in reducing the oxidative damage in maize (Pioneer-3335) under salt stress. Seedlings were transplanted to three levels of $\mathrm{K}(3,6$ and $9 \mathrm{mM})$ with $100 \mathrm{mM} \mathrm{NaCl}$ stress. Plant growth parameters, membrane stability index, $\mathrm{K}^{+} / \mathrm{Na}^{+}$ratio and antioxidant enzymes activity were reduced due to salt stress. Addition of $\mathrm{K}$ significantly improved the morphological and physiological attributes along with the antioxidant enzymes (SOD, CAT and POD) activity. With increasing $\mathrm{K}$ levels an improvement in crop growth was observed but the treatment with $9 \mathrm{mM} \mathrm{K}$ was found to give the best results. Maximum shoot and root lengths $(61.2$ and $30.6 \mathrm{~cm})$ were observed at $9 \mathrm{mM}$ applied $\mathrm{K}$ level. The similar trend regarding shoot and root fresh weight was observed for maize genotype. Improved membrane stability was observed at $9 \mathrm{mM} \mathrm{K}$ level in (Pioneer-3335) (75.6\%) under salt stress. Similarly, improved antioxidant enzymes (SOD, CAT and POD) activity was found in maize plants (35.5, 65.6 and 49.6 unit/g fresh weight) as compared to salt stress at $9 \mathrm{mM} \mathrm{K}$ level. The antioxidant enzymes activity was improved with the application of potassium under salt stress which ultimately induced oxidative stress tolerance in maize (Pioneer-3335).
\end{abstract}

Keywords: maize, salt stress, potassium, oxidative damage, antioxidant enzymes

Saline soil and water are the major constraints in reduced agricultural yield of many crops (Chaum et al., 2011; Ashraf, 2009; AzevedoNeto et al., 2006; Alam et al., 2000). The metabolic activities in most crops ceased due to higher salt concentration in soils that ultimately results in low agricultural productivity (Karsensky and Jonak, 2012; Munns and Tester, 2008; Cramer et al., 1996).

Along with osmotic stress, ionic imbalance and specific ion toxicity, the reactive oxygen species (ROS) generation is also coupled with salinity (Ali et al., 2011; Nabati et al., 2011; Gapinska et al., 2008; Mittler, 2002).

Among all other macro nutrients potassium has the significant role in plant survival under salt stress (Mahmood, 2011; Cherel, 2004; Mengel and Kirkby, 2001).

Keeping in mind these factors this study was planned to assess the ameliorative efficiency of potassium under salt mediated oxidative stress.

This study was conducted in the Institute of Soil and Environmental Sciences, University of Agriculture, Faisalabad, Pakistan. Three potassium levels (3, 6 and

*Author for correspondence; E-mail: sahirsuhaib@gmail.com
$9 \mathrm{mM}$ ) were applied with $100 \mathrm{mM} \mathrm{NaCl}$ stress. Maize genotype (Pioneer-3335) was used for this study. Maize seeds were germinated in sand containing trays and were transplanted in thermo pore sheets floating over Hoagland solution containing tubs at two leaf stage (Hoagland and Arnon, 1950). In respective saline treatments salinity was developed after two days of transplantation in 3 increments. $8 \mathrm{~h}$ daily aeration was provided through aeration pump and $\mathrm{pH}$ was maintained daily from 6-6.5.

After four weeks plants were harvested, recorded the growth attributes and stored in refrigerator for further analysis. The samples were analysed for membrane stability index according to method of Sairam et al. (2002). Sodium and potassium ion concentration was analysed using flame photometer.

Antioxidant enzymes activity (SOD, CAT, POD) was recorded using spectrophotometer from enzyme extract (For extracting antioxidant enzymes, $0.5 \mathrm{~g}$ fresh leaf samples were ground using a tissue grinder in $5 \mathrm{~mL}$ of $50 \mathrm{mM}$ cooled phosphate buffer $(\mathrm{pH} 7.8)$ placed in an ice bath. The homogenate is centrifuged at $15000 \times \mathrm{g}$ 
for $20 \mathrm{~min}$ at $4{ }^{\circ} \mathrm{C}$. The supernatant is used for determination of antioxidant enzymes) following the method of Giannopolitis and Ries (1977) for SOD by recording the decrease in absorbance of nitro blue tetrazolium $560 \mathrm{~nm}$ (1955). Catalase enzyme activity was recorded by calculating the decomposition of $\mathrm{H}_{2} \mathrm{O}_{2}$ at $240 \mathrm{~nm}$ and peroxidase enzyme activity was determined by recording the absorbance at $470 \mathrm{~nm}$ after $0 \mathrm{sec}$ for 5 min (Chance and Maehly, 1955). The experiment was laid out using CRD-Factorial arrangement and data was analyzed statistically using statistics 8.1. Plant growth attributes under salt stress have been shown in Table 1.

The data regarding $\mathrm{K}^{+} / \mathrm{Na}^{+}$ratio in maize genotype (Pioneer-3335) has been showed in Table 2. These results depicted the fact that saline environment subjects the plants to uptake more $\mathrm{Na}^{+}$as compared to $\mathrm{K}^{+}$hence decreasing the $\mathrm{K}^{+} / \mathrm{Na}^{+}$ratio. This ratio in plants grown in saline soils could be improved by the application of $\mathrm{K}$.

Table 1. Effect of potassium on growth parameters of maize grown under salt stress

\begin{tabular}{lllll}
\hline \hline Treatments & \multicolumn{4}{c}{ Pioneer-3335 } \\
\cline { 2 - 5 } & SL (cm) & SFW (g) & RL (cm) & RFW (g) \\
\hline Control & 99.9 & 45 & 42.4 & 6.47 \\
$100 \mathrm{mM} \mathrm{NaCl}$ & 50.1 & 21 & 22.5 & 3.25 \\
& $(50)$ & $(47)$ & $(53)$ & $(50)$ \\
$100 \mathrm{mM}$ & 53.3 & 23.9 & 24.2 & 3.67 \\
$\mathrm{NaCl}+3 \mathrm{mM} \mathrm{K}$ & $(53)$ & $(53)$ & $(57)$ & $(57)$ \\
$100 \mathrm{mM}$ & 58.1 & 28 & 27 & 4.44 \\
$\mathrm{NaCl}+6 \mathrm{mM} \mathrm{K}$ & $(58)$ & $(62)$ & $(64)$ & $(69)$ \\
$100 \mathrm{mM}$ & 61.2 & 31.5 & 30.6 & 5.12 \\
$\mathrm{NaCl}+9 \mathrm{mM} \mathrm{K}$ & $(61)$ & $(70)$ & $(72)$ & $(79)$ \\
\hline \hline
\end{tabular}

Values in () are the percentage of control. (SL, SFW, RL and RFW are the abbreviations of shoot length shoot fresh weight, root length and root fresh weight), respectively.

Table 2. Effect of potassium on $\mathrm{K}^{+} / \mathrm{Na}^{+}$ratio and membrane stability index of maize grown under salt stress

\begin{tabular}{lll}
\hline \hline Treatments & \multicolumn{2}{c}{ Pioneer-3335 } \\
\cline { 2 - 3 } & $\mathrm{K}^{+} / \mathrm{Na}^{+}$ratio & $\mathrm{MSI}$ \\
\hline Control & 2.67 & 88.6 \\
$100 \mathrm{mM} \mathrm{NaCl}$ & 0.46 & 60.2 \\
& $(17)$ & $(68)$ \\
$100 \mathrm{mM} \mathrm{NaCl}+3 \mathrm{mM} \mathrm{K}$ & 0.51 & 66.5 \\
& $(19)$ & $(76)$ \\
$100 \mathrm{mM} \mathrm{NaCl}+6 \mathrm{mM} \mathrm{K}$ & 0.56 & 71.2 \\
& $(21)$ & $70)$ \\
$100 \mathrm{mM} \mathrm{NaCl}+9 \mathrm{mM} \mathrm{K}$ & 0.60 & $(85)$ \\
& $(22)$ & \\
\hline \hline
\end{tabular}

Values in () are the percentage of control.
Results regarding antioxidant enzymes (SOD, CAT and POD) activity are presented in Table 3.

Table 3. Effect of potassium on antioxidants enzyme activity (SOD, CAT and POD) of maize grown under salt stress

\begin{tabular}{|c|c|c|c|}
\hline \multirow[t]{3}{*}{ Treatments } & \multicolumn{3}{|c|}{ Pioneer-3335 } \\
\hline & SOD & CAT & POD \\
\hline & \multicolumn{3}{|c|}{ (Unit/g FW) } \\
\hline Control & 25.6 & 64.6 & 43.8 \\
\hline $100 \mathrm{mM} \mathrm{NaCl}$ & $\begin{array}{l}24.7 \\
(96)\end{array}$ & $\begin{array}{l}53.4 \\
(82.8)\end{array}$ & $\begin{array}{l}41.9 \\
(95)\end{array}$ \\
\hline $\begin{array}{l}100 \mathrm{mM} \mathrm{NaCl} \\
+3 \mathrm{mM} \mathrm{K}\end{array}$ & $\begin{array}{l}26.9 \\
(105)\end{array}$ & $\begin{array}{l}58.7 \\
(91)\end{array}$ & $\begin{array}{l}44 \\
(100)\end{array}$ \\
\hline $\begin{array}{l}100 \mathrm{mM} \mathrm{NaCl} \\
+6 \mathrm{mM} \mathrm{K}\end{array}$ & $\begin{array}{l}32.1 \\
(125)\end{array}$ & $\begin{array}{l}61.9 \\
(95.9)\end{array}$ & $\begin{array}{l}47 \\
(105)\end{array}$ \\
\hline $\begin{array}{l}100 \mathrm{mM} \mathrm{NaCl} \\
+9 \mathrm{mM} \mathrm{K}\end{array}$ & $\begin{array}{l}35.5 \\
(138)\end{array}$ & $\begin{array}{l}65.6 \\
(101.6)\end{array}$ & $\begin{array}{l}49.6 \\
(113)\end{array}$ \\
\hline
\end{tabular}

Values in () are the percentage of control.

These results are supported by the facts that under salt stress plant photosynthesis rate, plant growth and biomass production is reduced (Akram et al., 2011; Sun et al., 2011; Cicek and Cakirlar, 2002). Application of $\mathrm{K}$ under saline treatment significantly improved membrane stability and plant growth parameters as supported by the fact that plant growth and yield of the crop is significantly increased by increasing the potassium dose (Fayez and Bazaid, 2013; Kaya et al., 2007; Nadia and Bardan, 2006).

From these results it is clear that ROS production is triggered under saline treatment $(100 \mathrm{mM} \mathrm{NaCl})$ and suppressing the activity of antioxidant enzymes (Yu and Rengel, 1999; Hernandez et al., 1995). Potassium is the major macro-nutrient that helps out the plants to overcome the salt stress conditions and its role in activating the enzymes is clearly depicted in this study that enhanced levels of $\mathrm{K}$ were helpful in improving the antioxidant enzymes activity. Such results are also previously revealed by Soleimanzadeh et al. (2010); Zheng et al. (2008).

\section{References}

Akram, M., Afzal, M., Ashraf, M. 2011. Detecting differences in some elite wheat lines for salt tolerance through multi parameters evaluation i.e. morphological and yield parameters. Pakistan Journal of Botany, 43: 435-443.

Alam, S.M., Ansari, A., Khan, M.A. 2000. Pakistan Salt Effected Soil Survey. Nuclear Institute of 
Agriculture, Tando Jam, Pakistan, pp. 8-21.

Ali, S., Zeng, F., Cai, S., Qiu, B., Zhang, G. 2011. The interaction of salinity and chromium in the influence of barley growth and oxidative stress. Plant Soil and Environment, 57: 153-159.

Ashraf, M. 2009. Biotechnological approach of improving plant salt tolerance using antioxidants as markers. Biotechnology Advances, 27: 84-93.

AzevedoNeto, A.D., Prisco, J.T., Eneas-Filho, J., Abreu, C.E.B., Filho, E.G. 2006. Effect of salt stress on antioxidative enzymes and lipid peroxidation in leaves and roots of salt-tolerant and salt-sensitive maize genotypes. Environmental and Experimental Botany, 56: 87-94.

Chance, B., Maehly, A.C. 1955. Assay of catalase and peroxidase. Method Enzymology, 2: 764-775.

Chaum, S., Pokasombat, Y., Kirdmanee, C. 2011. Remediation of salt-affected soil by gypsum and farmyard manure importance for the production of Jasmine rice. Australian Journal of Crop Sciences, 5: 458465.

Cherel, L. 2004. Regulation of $\mathrm{K}^{+}$channel activities in plants: from physiological to molecular aspects. Journal of Experimental Botany, 55: 337-351.

Cicek, N., Cakirlar, H. 2002. The effect of salinity on some physiological parameters in two maize cultivars. Bulgarian Journal of Plant Physiology, 28: 66-74.

Cramer, G.R., Alberico, G.J., Schmidt, C. 1996. Salt tolerance is not associated with the sodium accumulation of two maize hybrids. Functional Plant Biology, 21: 675-692.

Fayez, A.K., Bazaid, S.A. 2013. Improving drought and salinity tolerance in barley by application of salicylic acid and potassium nitrate. Journal of Saudi Society of Agricultural Sciences, 13: 45-55.

Gapinska, M., Sklodowska, M., Gabara, B. 2008. Effect of short and long-term salinity on the activities of antioxidative enzymes and lipid peroxidation in tomato roots. Acta Physiology of Plant, 30: 11-18.

Giannoopolitis, C.N., Ries, S.K. 1977. Superoxide dismutase-I. occurrence in higher plants. Plant Physiology, 59: 309-314.

Hernandez, J.A., Olmos, E., Corpas, F.J., Sevilla, F., DelRio, L.A. 1995. Salt-induced oxidative stress in chloroplasts of pea plants. Plant Sciences, 105: 151-167.

Hoagland, D.R., Arnon, D.I. 1950. The water-culture method for growing plants without soil. California Agricultural Experiment Station Circular, 347:
1-32.

Kaya, C., Tuna, A.L., Ashraf, M., Altunlu, H. 2007. Improved salt tolerance of melon (Cucumis melo L.) by the addition of proline and potassium nitrate. Environmental and Experimental Botany, 60: 397-403.

Krasensky, J., Jonak, C. 2012. Drought, salt and temperature stress-induced metabolic rearrangements and regulatory networks. Journal of Experimental Botany, 63: 1593-1608.

Mahmood, K. 2011. Salinity tolerance in barley (Hordeum vulgare L.) effects of varying $\mathrm{NaCl}, \mathrm{K}^{+} / \mathrm{Na}^{+}$and $\mathrm{NaHCO}_{3}$ levels on cultivars differing in tolerance. Pakistan Journal of Botany, 43: 1651-1654.

Mengel, K., Kirkby, E.A. 2001. Principles of Plant Nutrition, $5^{\text {th }}$ edition, Kluwer academic publisher, Dordrecht, Germany.

Mittler, R. 2002. Oxidative stress, antioxidants and stress tolerance. Trends in Plant Sciences, 7: 405410.

Munns, R., Tester, M. 2008. Mechanisms of salinity tolerance. Annual Review of Plant Biology, 59: 651-681.

Nabati, J., Kafi, M., Nezami, A., Moghaddam, P.R., Masoumi1, A., Mehrjerdi, M.Z. 2011. Effect of salinity on biomass production and activities of some key enzymatic antioxidants in kochia (Kochia scoparia). Pakistan Journal of Botany, 43: 539-548.

Nadia, M.B. 2006. Effect of potassium rate on barley growth and its mineral content under different salt affected soil conditions. Research Journal of Agriculture and Biological Sciences, 2: 512-519.

Sairam, R.K., Rao, K.V., Srivastava, G.C. 2002. Differential response of wheat genotypes to long term salinity stress in relation to oxidative stress, antioxidant activity and osmolytes concentration. Plant Sciences, 163: 1037-1046.

Soleimanzadeh, H., Habibi, D., Ardakani, M.R., Paknejad, F., Rejali, F. 2010. Effect of potassium levels on antioxidant enzymes and malondialdehyde content under drought stress in sunflower (Helianthus annuus L.). American Journal of Agricultural and Biological Sciences, 5: 56-61.

Sun, J.K., Li, T., Xia, J.B., Tian, J.Y., Lu, Z.H., Wang, R.T. 2011. Influence of salt stress on ecophysiological parameters of Periploca sepium Bunge. Plant Soil and Environment, 57: 139-144.

Yu, Z., Rengel, Q. 1999. Drought and salinity differentially influence activities of superoxide dismutase in narrow leafed lupines. Plant Sciences, 141: 1-11. 